\title{
The Old and New Malaya of Colonial Days and Its Continuity Into Modern Day Malaysia
}

\author{
Associate Professor Dr. Sivachandralingam Sundara Raja \\ Department of History, University of Malaya, 50603 Kuala Lumpur, Malaysia \\ siva@um.edu.my \\ Dr. Wu-Ling Chong
}

Department of Sociology, National University of Singapore, Singapore 117570

chong.wu.ling@gmail.com

Dr. Ahmad Kamal Arifin Bin Mohd. Rus

Department of History, University of Malaya, 50603 Kuala Lumpur, Malaysia

akamal@um.edu.my

\section{Doi:10.5901/mjss.2015.v6n2s1p161}

\section{Abstract}

The term "Old Malaya" refers to the Malay states of the eastern coast of the Peninsular (Kedah, Perlis, Kelantan and Terengganu) and the "New Malaya" to the states on the west coast (Perak, Negeri Sembilan, Selangor and Pahang). The British concentrated their economic growth on the west coast, thereby giving rise to a dual economy. On the west coast, the British were profit driven with special focus on mining and plantation sectors which reaped great economic growth. Similar policy was carried out by the post-independence government which focused more on the west coast states. This had serious implications and caused the east coast states to be underdeveloped. It is only very recently (2007) that the government planned to create the East Coast Economic Region (ECER) and Northern Corridor Economic Region (NCER) with major projects to improve the economic condition of the east coast states. The unequal development extended beyond regional inequalities, again as in the case of colonial rule. For instance, the Indians were marginalised both during the colonial era as well as in post-independent Malaya/Malaysia. The marginalisation of the Indians when plantations were bought over by government owned companies led to uneven development in post independent Malaya. This article intends to explore the uneven development of Malaya in the 19th and early 20th centuries, a situation which continued to exist in post-independent Malaya.

Keywords: Old Malaya, New Malaya, Malaysia, British colonialism, colonial economy

\section{Introduction}

This article examines the factors behind the uneven development of Malaya in the 19th and early 20th centuries and the impact of such an uneven development on post-independent Malaya/Malaysia. The uneven development of Malaya had led to the emergence of Old Malaya and New Malaya. It is pertinent to first understand the term Malaya as used in colonial times in both its geographical and political context before attempting to understand Old and New Malaya. In the 18th and 19th centuries, the term Malaya was used to denote the Malay Peninsula and the adjunct islands of Penang and Singapore. Until 1945 there were three political entities in Malaya:

1. The British colony of the Straits Settlements (known for short as the "S. S.") which included Penang (including the mainland territory of Province Wellesley) Malacca and Singapore. These territories were united in 1826 and Singapore became the capital in 1832.

2. The Federated Malay States (the "F. M. S.") of central Malaya comprising the states of Perak, Selangor, Negeri Sembilan and Pahang. The federation was formed in 1896 with Kuala Lumpur as its capital.

3. The Unfederated Malay States (the "U. M. S.") of Johor, Kedah, Perlis, Kelantan and Terengganu.

The nine Malay states of the F. M. S. and U. M. S. became British Protectorates at various times between 1874 and 1914. Malaya as a political entity came into being with the inauguration of the Federation of Malaya in 1948. 


\section{Research Method}

The method used in this research is library research. Library research was conducted by consulting both primary and secondary sources. The primary sources include the Tenth Malaysia Plan published by the Malaysian government, the statement by former prime minister of Malaysia during the launch of the East Coast Economic Region (ECER), and newspapers published in Malaysia. The secondary sources include books, journals and academic writings pertaining to the economic and social development of Malaya/Malaysia. This method is used because the sources consulted are reliable and provide comprehensive information on the economic and social development of Malaya/Malaysia, which is essential to this research.

\section{Old and New Malaya}

The terms "Old Malaya" and "New Malaya" were first used by by C. A. Vlieland (the Superintendent of the 1931 Census in Malaya) in "The 1947 Census of Malaya", Pacific Affairs, XXII, 1 March 1949. The British concentrated their economic growth on the west coast, thereby creating the conditions for the creation of a dual economy. The question to be raised is: what led to such a development? The answer could be found by tracing the economic development of the Malay states under British rule.

\section{Economic Growth under the Residential System}

British intervention in Perak under the Pangkor Agreement of 1874 saw the appointment of an official Resident and higher economic growth in Perak due to security, efficient administration and capital flow. Various steps were taken to encourage mining and agriculture. British policy on the whole could be classified as laissez-faire, which meant that they did not interfere in the affairs of the Europeans and the Chinese immigrants who were involved in the mining sector. If there was intervention, it was only to protect business interest. ${ }^{1}$ The principal source of revenue for the four Malay states, which were to come within British protection, was the export duty on tin. The next source was the duty imposed on imported opium, and the third on the import duties on spirits and the exclusive right to manufacture them for native consumption (Swettenham, 1983: 183-189). The Government also acquired revenue from land in the form of quit rent and premium payments as well as by providing postal, telegraphic and railway services. Between 1875-1896, tin was the main revenue earner $(\$ 25,989,664)$, followed by railway services $(\$ 6,726,48)$; land $(\$ 3,528,600)$; and postal and telegraph $(\$ 624,459)$ services (Sadka, 1968: 410-413). In terms of states, Perak was the top revenue earner, followed by Selangor, Negeri Sembilan and Pahang.

\section{Economic Growth under the Federation, 1896}

The inefficiency of the Residential system led to the need to amalgamate the four Malay States (Perak, Selangor, Negeri Sembilan and Pahang) under one central administration, with a federal executive, a Resident-General, as the head. The creation of a Federation led to standardisation and uniformity in land and mining law and other aspects of administration from 1896-1909. A tremendous growth was subsequently evident in the mining and agriculture sectors. The development of agriculture and mining was boosted through liberal land concessions; as well as special land regulations introduced after 1900. By the 1906 land terms, quit rent on agricultural land exceeding 10 acres was fixed at $\$ 1$ per acre per annum, rising to \$3- \$4 according to its classification (Lim, 1977: 95). Through the application of the lalang clause the state confiscated large tracts of abandoned land belonging to Chinese shifting cultivators (Jackson, 1968: 235). The

\footnotetext{
1 This could be seen in the case of the Federated Malay States (Perak, Selangor, Negeri Sembilan and Pahang). In these states, the natives and the immigrants did not perceive the British as interfering in their local affairs. In the agricultural sector, the British encouraged the importation of immigrants (Yip, 1969: 67). In 1853, in order to encourage exports, duties on export of tin to England were repealed. The British were indifferent to the formation of secret societies among the Chinese. The secret societies became a tool to recruit Chinese labourers and also played the role of a police force that served to maintain peace and order in the mines. Beside this, the British also encouraged road building and other infrastructure development. Until 1895, the British Government gave licenses to miners to operate tin mines which encompassed a small area (although it was uneconomic). This was done to encourage small scale industries and help Chinese miners who were accustomed to mining using labour intensive methods (Wong, 1965: 56). All these measures were seen as part of the laissez-faire policy. Refer also Sadka (1968: 336-337 and 348-349). Efforts by the Government to encourage investors in the Malay States are also discussed in detail in Sadka (1968: 336-337). For the performance of European firms from 1870-1890 refer Sadka (1968: 348-349).
} 
Government too established a Planters' Loan Fund which made large loans available cheaply and easily. The British administration also created a conducive environment that encouraged both agriculture as well as mining. Efforts were made to encourage infrastructure development in areas such as drainage, roads, railways and bridges with a view to boosting the plantation and mining economies.

It is also interesting to note that from the late 19th and early 20th centuries more European estates and mines were opened in the Malay States, and with that both planters as well as miners played a vital role in promoting investments, and had a bigger say in government policy (Butcher, 1979: 14-18).

\section{Factors Which Led to the Creation of Old Malaya and New Malaya}

\subsection{Commercial Crops Concentrated in the Straits Settlements and Western Malay States}

Prior to intervention, commercial crops were cultivated in the Straits Settlements and the Malay states. The earliest examples of plantation agriculture include pepper which was first grown in Kedah in the seventeenth century and then introduced into Johor in the 1840s, followed by nutmeg and cloves. Sugar estates were started by the Chinese in Province Wellesley and Malacca at the beginning of the nineteenth century. European planters on the other hand prefer to grow crops that were less demanding on both labour and soil, crops like tea, cinchona, gambier, pepper and coffee. Coffee was one crop which attracted European capital in the late nineteenth century.

\subsubsection{Sugar-cane}

The earliest commercial crops known to have been cultivated in the Straits Settlements and and later in the state of Johor and elsewhere in peninsula included sugar-cane, coffee, cotton and nutmeg. According to P. P. Courtenay (1972: 103), the pioneers of the sugar industry were the Chinese who reportedly started planting sugar cane in Province Wellesley shortly before 1800. However, the industry remained dominant until 1840. Between 1870 and 1900, sugar growing in southern Province Wellesley developed into a highly capitalised, European-controlled enterprise. Towards the end of the century the industry, at its peak had spread into the Krian district of neighbouring Perak. Between 1900 and 1914, the sugar industry of north-west Malaya declined to extinction (Courtenay, 1972: 98).

\subsubsection{Coffee}

Coffee was another important agricultural product cultivated in the Malay states and it was the only agricultural enterprise to be almost wholly European controlled after 1880 (Tate, 1979: 173). European coffee planters from Ceylon were attracted to Malaya when their estates were seized by the virulent fungus Hemileia Vastatrix in the early 1870s. By 1896, there were over 35,000 acres of European coffee planted in Perak with attractive land terms offered to planters. There were also considerable acreage in Selangor and Negeri Sembilan. The plantations of Selangor were concentrated to the north and north-east of Kuala Lumpur especially in the valleys of the Gombak and Setapak rivers. This concentration was due to the need for accessibility at a time when suitable roads were few in number, and also the fact that many of the estate pioneers were involved in road and railway contracting in Kuala Lumpur (Courtenay, 1972: 98). Table 1 shows the export of coffee from the Federated Malay States (F. M. S.) from 1898 to 1900.

Table 1: Coffee Exports from the Federated Malay States (F. M. S.)

\begin{tabular}{|c|c|c|c|}
\cline { 2 - 4 } \multicolumn{1}{c|}{} & 1898 & 1899 & 1900 \\
\cline { 2 - 4 } \multicolumn{1}{c|}{} & Pikuls & Pikuls & Pikuls \\
\hline Selangor & 22,948 & 26,407 & 34,295 \\
\hline Negeri Sembilan & 3,163 & 4,541 & 6,199 \\
\hline Perak & 2,837 & 932 & 4,269 \\
\hline Total & 28,948 & 31,880 & 44,763 \\
\hline
\end{tabular}

Source: Chai (1967: 151).

A sharp fall in world coffee prices occurred after the peak season of 1894-1895 due to Brazilian overproduction. By the time they began to recover after 1903, the industry had suffered other heavy blows. Hemileia vastatrix appeared in 
Selangor in 1894; and a caterpillar onslaught followed in 1899 (Tate, 1979: 202). This reduced the attractiveness of coffee growing in Malaya and shifted planters' interests to rubber for which a demand was beginning to emerge (Courtenay, 1972: 99).

Although short-lived as an export crop, coffee served as an important pioneer crop. For the first time (with the exception of the Province Wellesley sugar area), European capital was invested in agricultural development in Malaya. Land was cleared and minor roads constructed. Government policy was formulated to attract big time European planters. Land terms were easy and planting loans available. Channels were developed for the introduction of Tamil labour to work in the estates. With the advent of rubber after 1895, full advantage was taken of these earlier developments (Courtenay, 1972: 99). There is no doubt that the failure of coffee led to a policy of encouraging agriculture in Malaya.

\subsubsection{Rubber}

By the late 1890s rubber had been planted on an experimental basis in various parts of Perak. In 1905, 104 tons were exported from the F. M. S. The expansion of motor car and electrical industries caused the rise in world demand for rubber. New land regulations in the F. M. S. introduced low quit rents for land granted for rubber planting. These two factors stimulated interest in the cultivation of rubber. During the rubber boom of 1905-1908, virtually every estate introduced rubber on newly cleared fields, and in 1908 the crop was planted in every state, though especially in those of the west coast (Courtenay, 1972: 99). Table 2 shows the acreage under rubber cultivation in the F. M. S. from 1907 to 1909.

Table 2: Acres under Rubber Cultivation in the F. M. S

\begin{tabular}{|c|c|c|c|}
\hline & 1907 & 1908 & 1909 \\
\hline Perak & 46,167 & 56,706 & 68,278 \\
\hline Selangor & 61,552 & 82,246 & 93,853 \\
\hline Negeri Sembilan & 17,656 & 27,305 & 31,945 \\
\hline Pahang & 860 & 1,791 & 2,877 \\
\hline Total & 126,235 & 168,048 & 196,953 \\
\hline
\end{tabular}

Source: Chai (1967: 155).

From core areas associated with the location of the coffee estates, rubber spread onto unoccupied land within economic reach of the lines of communication developed to serve the tin fields. The Klang Valley with its road and rail links from Kuala Lumpur to Port Swettenham was the first major axis of development in Selangor, and away from this axis rubber planting was tied to the coastal roads out of Klang and to the north-south transport lines along the foothills from Kuala Lumpur. In Perak planting was similarly related to the transport axis through Batang Padang, Batu Gajah and Ipoh. Comparable development occurred along the roads and railways in Negeri Sembilan. In 1906, 80\% of the total area planted with rubber was in these three western states and the spread of planting into the other states of the peninsula was closely related to the extension of the road and rail network in subsequent years (Courtenay, 1972: 99).

It is clear the development of commercial agriculture in the Straits Settlements and Federated Malay States had created a new Malaya and ignored the east coast.

\subsection{Development of Tin Mining in the Western Malay States}

The tin industry has played a major part in the historical development of the Malay States. However, the transformation of the industry from a primitive and limited business into a highly capitalised and mechanised enterprise began in the nineteenth century in response to new demands generated by the Industrial Revolution in Europe (Tate, 1979: 185). This affected the Malay States and by the mid-1860s Straits tin was superseding both Bangka and Cornish tin and had regained its natural position as the premier tin export of Southeast Asia and the world. ${ }^{2}$

The growing demand for tin and rising prices stimulated the search for new deposits and it leading to the discovery

2 The reasons for the re-emergence of Straits tin lay primarily in Bangka's inability to cope with the rising demand for the metal from European consumers. At the same period the British market was also opening up, for the first time. In 1842 the British Parliament reduced tariffs on tin imports and preference was given to those imported tin from British territories. See Tate (1979: 223n.1). 
of several rich new fields between 1820 and 1879. When tin was discovered in Larut in the 1840s, Chinese labourers were imported to work the mines and soon they assumed virtual control of tin production. By the middle of the century, hundreds of Chinese were braving diseases and the unknown terrors of the Malayan jungle to look for tin in the interior of Perak and Selangor. Taiping and Kuala Lumpur became centres of intensive mining activities (Chai, 1967: 163).

Until 1880s tin production in Malaya was purely a Chinese monopoly. The earliest Europeans to break this monopoly were the French who in 1882 started operations in Kinta. Then the Australian and British miners tried to do the same. Between 1892 and 1908, eleven western companies were floated (Chai, 1967: 169). European companies which started before 1910 were not successful because they were burdened with the cost of hiring European staff, expensive equipment and heavy payments to promoters (Chai, 1967: 164-165).

The majority of European mines were opened between 1911 and 1929 and firms like Guthrie, Sime Darby, and Harrisons \& Crosfield, which had preponderant interests in the plantations became managing agents of most European mines. Chinese mines were responsible for the bulk of Malayan's tin export until 1929 and the smelting industry was monopolised by a European firm from a very early stage of the tin industry (Chai, 1967: 169-170). Comparative output of tin and the revenue from duty on tin are shown on Table 3 and Table 4 respectively.

Table 3: Comparative Output of Tin

\begin{tabular}{|c|c|c|c|}
\hline Year & World Production in tons & Malayan Production in tons & Malayan percentage \\
\hline 1898 & 78,600 & 41,167 & 52.3 \\
\hline 1899 & 76,100 & 38,960 & 51.1 \\
\hline 1900 & 85,400 & 43,111 & 50.4 \\
\hline 1901 & 92,900 & 47,475 & 51.1 \\
\hline 1902 & 88,700 & 47,258 & 53.2 \\
\hline 1903 & 93,900 & 50,842 & 54.1 \\
\hline 1904 & 95,600 & 51,733 & 54.1 \\
\hline 1905 & 98,900 & 50,991 & 51.5 \\
\hline 1906 & 102,500 & 48,672 & 47.4 \\
\hline 1907 & 101,600 & 48,474 & 46.7 \\
\hline 1908 & 108,700 & 50,868 & 43.9 \\
\hline 1909 & 115,400 & 50,754 & 39.4 \\
\hline
\end{tabular}

Source: Chai (1967: 176).

Table 4: Total Revenue of the F. M. S. and Receipts from the Export Duty on Tin

\begin{tabular}{|c|c|c|c|}
\hline Year & Revenue (\$) & Duty on Tin (\$) & Percentage of Tin Duty to Revenue \\
\hline 1898 & $9,364,467$ & $3,210,699$ & 34.2 \\
\hline 1899 & $13,486,410$ & $6,181,542$ & 45.8 \\
\hline 1900 & $15,609,807$ & $7,050,382$ & 45.1 \\
\hline 1901 & $17,541,507$ & $6,968,183$ & 39.7 \\
\hline 1902 & $20,550,543$ & $8,438,775$ & 41.0 \\
\hline 1903 & $22,672,567$ & $9,590,505$ & 42.3 \\
\hline 1904 & $22,255,269$ & $8,814,688$ & 39.6 \\
\hline 1905 & $23,964,593$ & $9,249,627$ & 38.5 \\
\hline 1906 & $27,223,476$ & $10,036,798$ & 36.8 \\
\hline 1907 & $28,793,745$ & $9,395,825$ & 32.6 \\
\hline 1908 & $24,623,325$ & $7,285,864$ & 29.5 \\
\hline 1909 & $25,246,863$ & $7,155,124$ & 28.3 \\
\hline
\end{tabular}

Source: Chai (1967: 176).

It is clear that the development of tin mining did lead to uneven development between the west and the east coast Malay states. 


\subsection{Uneven Development of Infrastructure in Favour of the Western Malay States}

With British intervention, the need to build roads and railway was necessary to encourage the rubber and tin industries. It was believed that improvements in transport and communications would encourage the flow of capital and labour which were considered necessary for economic development (Kaur, 1985: 8). This naturally meant that infrastructure development, following closely on the heels of economic development, was more evident in the west coast states as compared to the east coast.

\subsubsection{Railways}

The major railway network linking almost all the principal towns and ports of the country and running through most of the major rubber growing and tin mining districts was completed by 1931. There were four phases of growth in the Malayan railway system up to 1931. Phase 1 was between 1885 and 1899, when all the major tin mining towns and districts on the central west coast of Malaya, namely Perak, Selangor and Negeri Sembilan, were linked up with their respective ports. The primary object of capital formation in the railway sector in phase 1 was to facilitate the export of tin-ore and the import of mining equipment, foodstuff and other goods required by the tin mining industry (Lim, 1967: 272-273).

Phase 2 was between 1899 and 1904, when all the mining centers in Perak, Selangor and Negeri Sembilan were linked up longitudinally. The linkage was made complete in 1904 by a direct line from Prai running through the major mining towns and districts right up to Malacca (Lim, 1967: 273).

Phase 3 was from 1904 to 1909 when the Johor line linking Tampin to Gemas (1906), Gemas to Segamat (1908) and Segamat to Johor Bahru (1909) was completed. Three British Settlements were more or less linked up. The stretches of water separating Singapore and Penang islands from the mainland were bridged by railway ferries and coasters (Lim, 1967: 273).

During phase 2, rubber planting was already in full swing in Malaya and most of the rubber estates were located along the railway lines as the railway was the only modern transport available. When the railway network extended southwards to Johor in phase 3, rubber followed, and with rubber the Johor economy rose to a level of development that left many other Malayan States far behind (Lim, 1967: 273).

Phase 4 was between 1910 and 1931 when Prai via Bukit Mertajam was joined to Padang Besar, running through Kedah and Perlis, and Gemas was joined to Sungei Golok and Tumpat, leaving Trengganu to be the only state without any railway link. The East Coast line, that is, the line running from Gemas to Tumpat, was completed only in 1931. The Prai-Padang Besar line that was completed in 1918 gave Kedah a great time advantage, enhanced by its geographical proximity to Penang and Province Wellesly (Lim, 1967: 273-274).

\subsubsection{Roads}

When the first British Residents were appointed in Perak and Selangor in 1874, there were only two short stretches of cart roads in existence. The rest of the country was largely impenetrable jungle, and the only highways were the rivers. Therefore the first efforts at road construction were to join the mining centers with the rivers, and through the rivers to the sea-coast and from the sea-coast to the ports of Penang and Singapore (Lim, 1967: 276).

With the building of railways, the new road construction pattern was shifted to link mining centers with the railway lines instead of the rivers. With the rapid growth of the tin industry, existing townships expanded in size and new ones sprang up. More investment was made in road construction. By 1885, Selangor had a cart road linking with Perak and Negeri Sembilan. This road is the forerunner of the present main trunk road joining Singapore with the various WestCoast towns (Lim, 1967: 276-277).

The increasing use of motor vehicles after 1902 accelerated the road development plan. Since most of the main roads were constructed parallel to the railway lines, the increasing use of motor vehicles soon robbed the railways of their former traffic. By 1911, Prai was linked to Malacca. In the same period a road traversed the Peninsula horizontally linking Kuala Lumpur with Kuantan. By 1928, a road northwards via Alor Setar was extended to Kangar. Although by 1928 there was a road running from Singapore to Perlis, and a well-developed road network in most of the West Coast States, Terengganu was still left without a road, and Kelantan had just a few roads. Perlis was still underdeveloped and had to loan money from the Straits Settlements to build her only trunk road since road construction was left to the individual states. There is no doubt that the underdeveloped states (east coast) lagged behind compared to the developed ones in the provision of road facilities as in the supply of so many other types of social and economic infrastructure (Lim, 1967: 277-278). 
The decade after 1928 saw the further expansion of the road network. Road development took place mainly in the East Coast states and in Johor, chiefly in areas not served by the railways. In the east, a coastal road was constructed linking Kota Bharu to Kuala Terengganu, and from Kuala Terengganu to Chukai. In Pahang, a new coastal road was constructed to link Kuantan to Pekan, and from Pekan to Nenasi. However there was still no road link between Pahang and neighbouring Terengganu (Lim, 1967: 278). Peninsular.

The development of railways and roads clearly indicate that the focus of development was on the west coast of the

\section{Impact of Economic Expansion on the East Coast States}

As explained, since most of the major agricultural and tin mining activities were actively carried out in the west coast states, railway lines and roads that served the tin mines and rubber estates were mainly located on the west coast. The east coast states like Kelantan and Terengganu were lacking in railway lines and roads for quite some time after the network of railway and roads in the west coast were almost completed. Most of the banks and commercial companies were not established in the East Coast States due to lack of infrastructure. According to Allen and Donnithorne, when the rubber planters arrived, the location of their estates was determined mainly by the existing road system. Therefore the west coast was the scene of the outstanding economic developments after the turn of the century and attracted most of the immigrants, Chinese and Indian. In contrast, the states of Pahang, Kelantan and Terengganu remained comparatively backward (Allen and Donnithorne, 1957: 43). This accentuated a dual economy whereby the west coast states enjoyed far more economic development than the east coast. Table 5 gives an idea of the dual economy.

Table 5: Percentages of Economically Active Persons in Each Main Industrial Sector in Each State, 1957

\begin{tabular}{|c|c|c|c|c|c|}
\hline \multirow{2}{*}{\multicolumn{2}{|c|}{ State }} & \multicolumn{4}{|c|}{ Industrial Sector } \\
\hline & & \multirow{2}{*}{$\begin{array}{c}\text { Primary } \\
31.7 \\
\end{array}$} & \multirow{2}{*}{$\begin{array}{c}\text { Secondary } \\
16.4 \\
\end{array}$} & \multirow{2}{*}{$\begin{array}{c}\text { Tertiary } \\
51.8 \\
\end{array}$} & \multirow{2}{*}{$\frac{\text { Total }}{100.0}$} \\
\hline \multirow{6}{*}{ 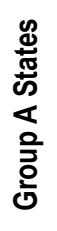 } & Penang & & & & \\
\hline & Selangor & 48.7 & 15.1 & 36.3 & 100.0 \\
\hline & Malacca & 53.1 & 13.5 & 33.4 & 100.0 \\
\hline & Perak & 62.9 & 9.5 & 27.6 & 100.0 \\
\hline & Johor & 66.6 & 7.5 & 25.9 & 100.0 \\
\hline & Negeri Sembilan & 66.7 & 7.8 & 25.5 & 100.0 \\
\hline \multirow{5}{*}{ 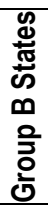 } & Terengganu & 71.3 & 11.1 & 17.6 & 100.0 \\
\hline & Pahang & 72.6 & 6.6 & 20.8 & 100.0 \\
\hline & Kedah & 77.6 & 7.0 & 15.4 & 100.0 \\
\hline & Kelantan & 76.8 & 5.6 & 17.7 & 100.0 \\
\hline & Perlis & 81.9 & 4.1 & 14.1 & 100.0 \\
\hline & STATES & 62.9 & 9.8 & 27.3 & 100.0 \\
\hline
\end{tabular}

Source: $\operatorname{Lim}(1967: 203)$.

The above table distinguishes the primary sector (agriculture, forestry, hunting, fishing and mining) from the secondary sector (manufactures, building and construction, etc) and the tertiary sector (mainly services) (Lim, 1967: 201, 203).

It shows that the secondary and tertiary sectors were relatively more developed in Penang, Selangor and Malacca. Each of these three states had an important port, and entrepot trade had contributed to the importance of the tertiary sector. In contrast, the East Coast States like Terengganu, Kelantan and Pahang had a higher percentage of primary sector labour. They had remained essentially paddy-growing and fishing states.

\section{The Relevance of Old Malaya and New Malaya in Contemporary Malaysia}

The scenario which was created by the colonial masters did not change much after independence. Although the colonial and independent government implemented economic programmes such as Draft Development Plan 1950-55; First Malaya Plan 1956-60; Second Malaya Plan 1961-65 (identified with what later came to be known as the old economic policy) and Malaysia Plans from 1966-2010 (under the New Economic Policy), the East Coast Malay States continued to lag behind the West Coast States in terms of economic progress. This led the government to introduce what is known as the East Coast Economic Region (ECER) and Northern Corridor Economic Region (NCER) project in 2007 to improve the 
economic condition of the East Coast States.

The East Coast Economic Region (ECER) covers the states of Kelantan, Terengganu, Pahang and the district of Mersing in the state of Johor and focuses on four thrust areas - tourism, oil, gas and petrochemical manufacturing, agriculture and education (Tenth Malaysia Plan, 2011: 118-119). With an area measuring more than 66,000 sq km, ECER covers more than half of Peninsular Malaysia. A Master Plan was developed to be the basis for guiding the development of this region until 2020 when it will be transformed into a major international and local tourism destination, an exporter of resource based and manufactured products, a vibrant trading centre, and an infrastructure and logistics hub. The main objective of the ECER Master Plan is to accelerate the growth of the East Coast Economic Region in a viable, equitable and sustainable manner (See the ECER's official website at http://www.ecerdc.com.my).

The Northern Corridor Economic Region (NCER) covers the northern states of Perlis, Kedah, Pulau Pinang and northern Perak (districts of Hulu Perak, Kerian, Kuala Kangsar and Larut Matang-Selama), covering an area of 17,816 sq $\mathrm{km}$ (See the NCER's official website at http://www.koridorutara.com.my). It focuses on accelerating economic growth and elevating income levels in northern Peninsular Malaysia with the objective of transforming it into a world-class economic region by the year 2025. It leverages on the existing economic achievements of the region in electronics, tourism and agriculture, as well as its strategic location bordering Thailand and facing the Malacca Straits. Leveraging on the strengths of the region, four key thrust areas have been identified, namely agriculture, manufacturing, tourism and logistics (See the NCER's official website at http://www.koridorutara.com.my).

When the ECER was launched, it was admitted by the Prime Minister that after 50 years of independence, the rates of growth have been uneven. Certain areas have enjoyed growth and development at a faster pace than others and there is thus a need to close these regional gaps (See the statement by Prime Minister Datuk Seri Abdullah Badawi during the launch of ECER, available at http://www.ecerdc.com.my). This is a clear indication that the post independent government had all along been pursuing a policy which neglected the east coast. In other words, Old Malaya continued to persist long after the country attained its independence in the latter half of the twentieth century.

\section{Reasons for Uneven Development after Independence}

Recent findings claim that Kelantan and Sabah are the poorest states in the Peninsula and West Malaysia respectively (Mohamad, 2013: 62). Kelantan's mean monthly household income was found to be the lowest in the country at RM 2,536 compared to RM 4,025 for the whole country (Mohamad, 2013: 241, quoting Haji Mat Zin, 2008: 114-132). This poses a serious question, as to what caused such a situation to occur even after Malaya got its independence. There are a few reasons why this situation persisted. The discussion below will address these issues.

\subsection{Foreign Advisers behind Malaya and Malaysia Plans}

Immediately after independence, the British introduced economic policy known as Malaya Plans (1955-60); Second Malaya Plans (1961-65) and later Malaysia Plans from 1965 onwards. The Malaya Plans and the first three Malaysia Plans that followed were said to be masterminded by foreign expertise from the United States of America (USA) (Amri Baharuddin, 1979: 345). The earliest Malaysia Plan was drafted with the advice of Prof. Warren Hansbuger from USA; the second plan with the help of Prof. V.M. Bernett, Dr. D. Snodgrass and Prof. H.J. Bruton, also from the USA. The third plan had the advice of Prof. B. Higgins, also from the USA. Therefore it was no surprise that the early Malaysia Plans were largely aimed at safeguarding foreign interests concentrated on the West Coast States, rather than solving the imbalances engendered by the colonial economy.

\subsection{Early Malaya and Malaysia Plans Fail to Address Core Issues}

Malaysia Plans, be they from the earlier years of independence or more recent ones, have failed to focus on the core matters which cause poverty. Emphasis was mainly on the need to introduce capital and technology, thereby ignoring the real problem of poverty in the rural sector. There has been a tendency to divide modern from traditional sectors when in reality both sectors had strong structural links with one another. This was obvious during British rule when the traditional sector was the supplier of raw materials to the British industry. This led to the transition from subsistence to commercial economy (Amri Baharuddin, 1979: 345).

The flaw was evidenced in the Second Malaysia Plan when it identified poverty among the farmers to uneconomic use of land and continued use of traditional techniques/methods to cultivate the crops. The real reason for the poverty was due to the exploitation by middle-men; and land ownership by capitalists who exploited farmers working for them 
(Amri Baharuddin, 1979: 346). It has to be noted that rural impoverishment could be traced to colonial rule and the solution needed to be seen in the broader context.

\subsection{Post-Colonial Centralism}

The lopsided development of the country is but a reflection of a larger tendency towards centralism that sought power and authority for a dominant group of power wielders over the rest of society that included minority groups (be they fringe political opponents or ethnic minorities). According to recent studies, post-colonial centralism reared its head after 13 May 1969 (race riot), whereby the National Front (coalition government) strengthened its powers and exercised complete control over the executive and other branches of governance as well (Ooi, 2013: 321). It saw UMNO, the dominant party within the coalition controlling the direction of politics in the country. The concept of "kerajaan berparti" (government with the party) tied the government structure tightly to the party apparatus (Ooi, 2013: 322). The Petroleum Development Act (1974) and the Industrial Coordination Act (1975) were clear examples how the government managed to exploit its political power to shape economic development (Ooi, 2013: 324). It is not far-fetched to claim that from the 1970s onwards, the central government seriously attempted to transform the colonial economy into a national economy (Ooi, 2013: 324). But this led to the "Malay first" policies which became obvious in the Mahathir era (1981-2003).

The centralism did not allow room for open discussion on issues relating to exploitation and class injustices. Many decisions were made by UMNO/Prime Minister without having to raise the related issues in Parliament. One good example is the announcement by the government in 2013 that RM 30 billion will be allocated for programmes that empower the "bumiputeras" or natives of the land. This led to grouses among the public and the writer too has aired his displeasure to the media. To quote the author:

It is indeed a pity that the government has rushed into the Bumiputra Economic Empowerment Plan (BEEP) lending credence to the perception that it is an UMNO agenda linked not with poverty, but with increasing lust and greed. The policy was also a way of thanking the Malay and Bumiputra communities who had "supported, given their mandate and trust to Barisan Nasional at the 13th General Election to continue the leadership of the nation", resulting in BN's ability to increase its parliamentary seat from 79 to 88 .

It is sad that an important policy such as the BEEP, is going to end up like the NEP, which has been hijacked to empower the richest bumiputras. Unfortunately these policies are never endorsed by the elected representatives. And yet we learn in our text books that one of the functions of a parliament is to scrutinize government policies and debate the major issues of the day.

It is clear that in Malaysia, like in many other third world countries, Parliament is handicapped, unable to discuss policies, or hold the government to account.

With Najib's short sighted policies in place, the country may never attain Vision 2020. Maybe the only way out for Malaysia's ailing economy is to strictly implement the Trans Pacific Partnership Agreement. This may be the only way out, if our economy is not to be brought to its knees.

(Sundara Raja, 2013) ${ }^{3}$

\subsection{Government Plans are Exclusive}

The various Malaysia Plans have failed to include the people of all races in need of assistance. Studies done by Rusaslina Idrus, Zawawi Ibrahim and Andrew Aeria prove that the Bumiputeras of Sabah and Sarawak; Indians and ethnic groups in Sabah and Sarawak and the aboriginies of Peninsular Malaysia (orang Asli) were excluded from poverty eradication programmes (Gomez, Saravanamuttu and Mohamad, 2013: 17). Although affirmative action policy of the government aims to reduce poverty, it sadly ended up being exploited by the rich (Gomez, Saravanamuttu and Mohamad, 2013: 17).

Spatial disparities had worsened after the NEP was implemented because the preferences designed to encourage Bumiputera entreprenurship were disproportionately utilised by members of the targeted group in urban and prosperous rural areas (Gomez, Saravanamuttu and Mohamad, 2013: 10). According to Gomez, Saravanamuttu and Mohamad,

There is a clear proof that government economic policies fail to make facilities accessible to the most in need. There seems to be strong intra-Bumiputera wealth and income disparities. The poor access of those in most need of government support is reflected in a clear spatial divide that has emerged, with poverty most severe in the Bumiputera heartland states in the peninsula, particularly in Kelantan, Terengganu, Kedah and Perlis. The widening disparity between

${ }^{3}$ Only a part of the original write-up was published in Sundara Raja (2013). 
the East and West Malaysia is another obvious failure, evidenced by poverty among non Malay Bumiputeras in Sabah and Sarawak and by the fact that Sabah is the poorest state in the country.

(Gomez, Saravanamuttu and Mohamad, 2013: 17)

The disparity led to protest by minority groups, especially the poor Indians and the orang Asli. This message was conveyed by the Hindu Rights Action Force (HINDRAF) movement in 2007 which brought the plight of the poor Indians to public scrutiny, and proved that hard-core poverty is an issue that transcends ethnicity (Gomez, Saravanamuttu and Mohamad, 2013: 15). HINDRAF made the government realise the rights of the marginalised segments of society to be treated as a part of the nation.

\section{Marginalisation of the Indians in the Post-Independence Era}

Similar to what the East Coast States of Malaya witnessed during the colonial period, the Indians too were a neglected lot under British rule, Japanese occupation and after independence. During colonial rule, Indians were an asset for the British in the plantation sector (especially in the rubber industry as well as building of roads and railways). Although there were specific programmes for the socio-economic upliftment of the Malays and the Chinese, sadly the same did not apply to the Indians who had a difficult time in the estates. Although the MIC was a partner within the ruling coalition, it was not in a position to demand anything significant from the government for the socio-economic upliftment of the Indian community. Their grouses led to the eventual emergence of HINDRAF as a result of which confrontation, the National Front lost many seats in the 2008 general elections. That the Indians were marginalised both by the British and the government in power after independence was admitted by the current Prime Minister in 2013. This admission was reflected in the formulation of various government programmes such as infrastructure development of Tamil schools for which RM 540 million was allocated in 2009; building of seven new Tamil schools; establishing the 'Action Plan for Tamil Schools Unit' under the Prime Minister's Department to monitor Tamil school issues and chart a blueprint for the future of these schools; provision of free primary and secondary school education in government schools since 2012; allocation of 1,000 additional seats for Indian students in government matriculation colleges, thereby bringing the total to about 1,500; introducing an annual quota of 10 percent of places in government polytechnics for Indian students; allocating RM50 million for skills training programs aimed at Indian youths from plantation background; reserving RM 150 million to be given out in loans for small and medium enterprises owned by Indian; allocating RM 100 million under Amanah Ikthiar Malaysia to be dispensed as micro-credit for Indian women; providing RM8 million in funding to transform existing Indian sundry shops and automotive workshop; and establishing the Special Secretariat for the Empowerment of Indian Entrepreneurs to help Indian businesses to obtain financing and advisory services ("Report Card on the Indian Community", 2014). Another admission was that it took 35 years for two Indians to be granted full ministerial posts in the Cabinet (the last was during Tun Razak's premiership) and promoting many Indian Malaysians to senior positions in government.

This proves that the Independent government of Malaya/Malaysia followed on the footsteps of the colonial masters in pursuing policy which failed to draw the Indians into the mainstream development of the nation.

\section{Conclusion}

It is evident that British economic expansion in Malaya had brought outstanding economic development to most parts of the west coast. However, the development along the east coast was neglected. This led to the phenomenon best described as a dual economy expressed sometimes in terms of Old Malaya and New Malaya. Such division was due to the deliberate policy pursued by the British by making sure the east coast continued to remain as the rice bowl of the country; expected to feed the population of the west coast. No attempt was made to develop the east coast by creating economic opportunities and investing in the agricultural and mining sector. After independence, the concentration of economic activities on the west coast of the peninsula, as well as the accumulation of wealth in urban localities resulted in unequal development. Although the government tried to overcome this imbalance through various attempts, the imbalance continued to persist. Some states such as Kelantan, Sabah and Sarawak were left behind. This also led to poor national integration. The attempts by the present government to develop the east coast through corridors like ECER and NCER are an indirect admission of unwholecome development since Independence. A similar faith befalls the minorities and one of them is the Indian community whom the government tried to bring into mainstream development after the HINDRAF uprising of 2007. It is crystal clear that the dichotomy of Old and New Malaya continued well into modern Malaysia even after independence and way into the 21st century. 


\section{References}

Allen, G. C., \& Donnithorne, A. G. (1957). Western Enterprise in Indonesia and Malaya. New York: Macmillan.

Amri Baharuddin, S. (1979). Perancangan Pembangunan Negara Selepas Merdeka 1957-1975: Tinjauan Sejarah Perkembangan SosioEkonomi Malaysia. In K. K. Khoo, \& J. Baharuddin (Eds.), Sejarah Proses dan Pembangunan (pp. 335-347). Kuala Lumpur: Persatuan Sejarah Malaysia.

Butcher, J. G. (1979). The British in Malaya, 1880-1941, The Social History of the European Community in Colonial South -East Asia. Kuala Lumpur: Oxford University Press.

Chai, H. C. (1967). The Development of British Malaya 1896-1909. Kuala Lumpur: Oxford University Press.

Courtenay, P. P. (1972). A Geography of Trade and Development in Malaya. London: G. Bell and Sons, Ltd.

Gomez, E. T., Saravanamuttu, J., \& Mohamad, Maznah. (2013). Malaysia's New Economic Policy: Resolving Horizontal Inequalities, Creating Inequities? In E. T. Gomez, \& J. Saravanamuttu (Eds.), The New Economic Policy in Malaysia: Affirmative Action, Ethnic Inequalities and Social Justice, edited by Edmund Terence Gomez and Johan Saravanamuttu (pp. 1-28). Singapore: NUS Press.

Haji Mat Zin, R. (2008). Income Inequality in Malaysia. Asian Economic Policy Review, 3(3), 114-132.

Jackson, J. C. (1968). Planters and Speculators. Kuala Lumpur: University of Malaya Press.

Kaur, A. (1985). Bridge and Barrier. Singapore: Oxford University Press.

Lim, C. Y. (1967). Economic Development of Modern Malaya. Kuala Lumpur: Oxford University Press.

Lim, T. G. (1977). Peasants and their Agricultural Economy in Colonial Malaya. Kuala Lumpur: Oxford University Press.

Mohamad, M. (2013). The New Economic Policy and Poverty at the Margins: Family Dislocation, Dispossession and Dystopia in Kelantan. In E. T. Gomez, \& J. Saravanamuttu (Eds.), The New Economic Policy in Malaysia: Affirmative Action, Ethnic Inequalities and Social Justice (pp. 61-82). Singapore: NUS Press.

New Straits Times (Malaysia). (2014). Report Card on the Indian Community, 19 \& 20 February.

Ooi, K. B. (2013). The New Economic Policy and the Centralisation of Power. In E. T. Gomez, \& J. Saravanamuttu, The New Economic Policy in Malaysia: Affirmative Action, Ethnic Inequalities and Social Justice (pp. 317-333). Singapore: NUS Press.

Sadka, E. (1968). The Protected Malay States. Kuala Lumpur: University Malaya Press.

Statement by Prime Minister Datuk Seri Abdullah Badawi during the launch of ECER. (n.d.). [Online] Available: http://www.ecerdc.com. my.

Sundara Raja, S. (2013). Let Parliament scrutinise policies. The Sun (Malaysia), September 13. [Online] Available: http://www. thesundaily.my/news/834845.

Swettenham, F. A. (1983). British Rule in Malaya. In P. H. Kratoska (Ed.), Honourable Intentions: Talks on the British Empire in SouthEast Asia Delivered at the Royal Colonial Institute, 1874-1928 (pp. 170-211). Singapore: Oxford University Press.

Tate, D. J. M. (1979). The Making of Modern South-East Asia, Vol. 2: The Western Impact. Kuala Lumpur: Oxford University Press. Tenth Malaysia Plan. (2011). Kuala Lumpur: Government Printers.

Vlieland, C. A. (1949). The 1947 Census of Malaya. Pacific Affairs, XXII(1), 59-63.

Wong, L. K. (1965). The Malayan Tin Industry to 1914. Tuscon: University of Arizona Press.

Yip, Y. H. (1969). The Development of the Tin Mining Industry of Malaya. Kuala Lumpur: University of Malaya Press. 